\title{
TYPES OF SCIENTIFIC DESCRIPTIONS IN ROMANIAN GEOGRAPHY TEXTBOOKS
}

\author{
VIORICA BLÎNDA \\ Secondary School No. 7, Botoşani, Romania, e-mail: blanda_viorica@yahoo.fr
}

(Received: October 2011; in revised form: December 2011)

\begin{abstract}
This study will provide a brief look into the numerous aspects of description as a unit of discourse and into the/as well as into those/distinctive discourse methods. The perspectives of the proposed analysis emphasize that description as a unit of discourse is no longer denigrated and that it has regained its well-defined place within the discourse (especially within the discourse of geography as a primary unit of discourse). The analysis is based on a corpus of studies represented by texts of geography available in geography textbooks. Through this study there will be outlined a number of methods and strategies of the discursive process through description.
\end{abstract}

Keywords: description, descriptive process, referentiality, anchor, aspectualization

\section{NTRODUCTORY REMARKS}

In his recent study on descriptive texts, the linguist Jean-Michel Adam underlined the fact that description, as a discursive unit, "was less studied" (2007, p. 9). According to linguists' opinion, description was criticised during the period of classicism because "it was more precise, rational, and universal than its definition" (Charaudeau, Maingueneau, 2002, p. 165). Therefore, they considered that description "never surprised the essence of beings and of objects because it based itself on the accidental and on the unique" saying that it was seen as "an unsatisfying and mediocre copy of reality" (Charaudeau, Maingueneau, 2002, p. 165).

In the scientific description, there was a certain order in exposing the features of objects as compared to the literary description that was free and having no order. In comparison to the literary description which was subjective, scientific description insisted very much on enumeration that, as an inventory list, was oriented towards giving arguments, approaching 
selection, making lists (orderings) "in order to form the sense of a text and/or of a situation", an idea supported by Jean-Michel Adam (2007, p. 194).

Scientific descriptive sentences are organised in tables and authors insisted on making lists, giving explanations, making changes and fighting against the inventory list. Through the scientific description, authors revealed in a suggestive way both the common features and the distinctive ones of objects, of beings, and of geographical phenomena. They presented these features in a clear and objective manner, at the same time offering explanations and arguments in a sober scientific style. Through description authors revealed why something was different from something else due to certain qualities. Authors described geographical objects according to certain variables: height, depth, colour, surface/area (an area where an element appeared), polarisation, gradient, flux, texture, source/spring, composition, etc.

Scientific description offered an encyclopaedic type of information about geographical places in the present, about beings and objects in the geographical reality.

\section{GEOGRAPHI CAL DESCRI PTION TYPES}

\section{Topographical description}

Through topographical description authors maintained the identity of certain places by naming them and thus they realised the processes of differentiation, aspectualisation, making emblems, personalisation, making hierarchies, and classification.

The cause of the unique features of the Transylvanian Depression was its size: "The large interior depression area - the Transylvanian Depression - is a characteristic feature. Nowhere within the young mountains of Europe does such a large interior depression exist." Through description, in the text below, the authors explained proper names, as for instance: the toponyms of the three branches of the Carpathians were given according to their location in relation to the Transylvanian Depression: "According to their position relative to this depression area, the neighbouring Carpathians bear the following names: the Eastern Carpathians, the Southern Carpathians, and the Western Carpathians."

The text below that I chose for illustrating topographical description began with naming a certain area with the name the Carpathians and continued with details on localisation and their altitude as a variable in the Alpine system using the phrase: "a lower altitude prolongation of the Alps". Then, a precise description of the localisation of the Carpathian Mountains followed: "They begin at the Danube, in the Vienna Basin and, after a large elbow on the territory of our country; they end at the south of the Danube, in the depressions on the Timok Valley, near those laying the Stara Planina Mountains (the Balkans)." In this description of localisation, we identified a 
phrase that described form: "a large elbow". The authors described other features of these mountains through aspectualisation: "their sinuous route", "many depressions and large valleys", "offering good spaces for inhabiting and facilitating crossing from one side of the mountains to the other one". The authors compared these mountains with the Alps and with the Balkans using the height variable: "their lower altitude than that of the Alps, but a little higher than the Balkans." They also included these mountains in a temporal category: "in the category of the young mountains of Europe (that rose through repeated shrivellings at the end of the Mesozoic and of the Neozoic eras)".

Text no. 1:

"The Carpathians are a lower altitude prolongation of the Alps. They begin at the Danube, in the Vienna Basin and, after a large elbow on the territory of our country; they end at the south of the Danube, in the depressions on the Timok Valley, near those laying the Stara Planina Mountains (the Balkans). The Carpathians are in the category of the young mountains of Europe (that rose through repeated shrivellings at the end of the Mesozoic and of the Neozoic eras). Their sinuous route and their lower altitude than that of the Alps, but a little higher than the Balkans, as well as the many depressions and large valleys are characteristic of these mountains, offering good spaces for inhabiting and facilitating crossing from one side of the mountains to the other one. The large interior depression area - the Transylvanian Depression - is a characteristic feature. Nowhere within the young mountains of Europe does such a large interior depression exist. According to their position relative to this depression area, the neighbouring Carpathians bear the following names: the Eastern Carpathians, the Southern Carpathians, and the Western Carpathians." (Tufescu, Giurcăneanu, Anastasiu, 2000, Geografia României - Manual pentru clasa a XII-a [The Geography of Romania - Textbook for the $12^{\text {th }}$ Grade], p. 9)

The many names of places in the text (the Carpathians, the Alps, Vienna, the Danube, the Balkans, the Stara Planina, the Timok Valley, Europe, the Transylvanian Depression, the Eastern, the Southern, and the Western Carpathians) are a clue that this was a topographical description. They were the nuclei around which authors conceived their description and realised the individualisation of the Carpathians. The named object "the Carpathians" showed us through the appellative mountains that it was a text about a major landform identified through the proper name the Carpathians and through the mountain proper names the Eastern, the Southern, and the Western, we learnt about the divisions of these mountains and their localisation according to the cardinal points.

\section{Chronographic description}

Chronographic description showed the time and answered to the question "when?", relating geographical events to geological time. There were 


\section{VIORICA BLÎNDA}

descriptions for geographical processes and phenomena that developed in time, in well defined periods, either in the geological past or in the present.

In the following text, the authors themselves revealed the use of chronographic description: "In order to understand the genesis and evolution of these areas it is necessary to understand the geological changes that took place in the nearby European regions, in the periods when the first areas of land appeared on the territory of our country".

Text no. 2:

"Stages in the genesis of the landforms of Romania

The present landforms of our country are the result of the changes that the land cover underwent during geological eras under the action of internal and external factors. In order to understand the genesis and evolution of these areas it is necessary to understand the geological changes that took place in the nearby European regions, in the periods when the first areas of land appeared on the territory of our country.

In the Archaic and Proterozoic Eras, the oldest areas of the land of Europe were in the north of the continent - the Baltic Shield- and in its east, the Eastern European Platform. They were made of crystalline schist and granite intrusions. The basis of the Eastern European Platform descends slowly towards the Eastern Carpathians, it forms the basement in the north-eastern part of the Moldavian Tableland and is covered with Palaeozoic, Mesozoic, and Neozoic sedimentary deposits, out of which the Mesozoic ones can be seen in the banks of the River Prut, and the Neozoic ones along its tributaries." (Tufescu, Giurcăneanu, Anastasiu, 2000, Geografia României Manual pentru clasa a XII-a [The Geography of Romania - Textbook for the $12^{\text {th }}$ Grade], p. 6)

The chronographic markers characteristic of Geography were the geological eras (Palaeozoic, Mesozoic, and Neozoic) and their periods. According to these eras and their periods, the authors situated from a temporal perspective the sedimentary deposits "out of which the Mesozoic ones can be seen in the banks of the River Prut, and the Neozoic ones along its tributaries".

Authors presented some events from a historical temporal perspective such as the process of inhabiting the Carpathian-Danube-Black Sea space in: the prehistoric period, in the Palaeolithic, in the Neolithic, in the Bronze Period, in the Dacian-Roman Period, in the Middle Ages, as illustrated in the text below:

Text no. 3:

"The Carpathian-Danube-Black Sea space had favourable conditions for inhabiting starting with the prehistoric period and a proof consists of the vestiges discovered on the Dârjov Valley (near Slatina), in Mitoc (on the River Prut), etc. Historians wrote about over 200 settlements dating back to the Palaeolithic, and other 2000 dating back to the Neolithic and to the 


\section{TYPES OF SCIENTIFIC DESCRIPTIONS IN ROMANIAN GEOGRAPHY TEXTBOOKS}

Bronze Period. (...) Starting with the $7^{\text {th }}$ and $6^{\text {th }}$ centuries before Christ, the Greeks built urban fortresses. The Dacian-Roman Period was characterised by developed rural settlements, towns and castra. (...) In the Middle Ages towns reappeared first as bourgs and fortresses, and villages increased their number." (Posea, 2000, Geografia României. Manual pentru clasa a VIII-a [The Geography of Romania. Textbook for the $8^{\text {th }}$ Grade], pp. 62-63)

\section{DESCRI PTI VE PROCEDURES}

\section{Consecutive description}

In order to reveal consecutive description, we chose to present similarities and contrasts between the biomes of the biogeographical zone characteristic of the cold climate.

In the following text, the authors described the geographical whole of the tundra in a synecdoche, describing its parts: the Arctic tundra, the Antarctic tundra, and the cold deserts that have different locations. Thus, we could identify, explain, and give arguments for the hidden cause-effect relationships. The "presence of the turf moors" was the characteristic feature of the Arctic tundra. Why turf moors? Because of humidity. Why was the Arctic tundra "an association of grass, moss, lichens, and shrubs?" Because of the strong winds, of low temperature, and of humidity. The clues for identifying the being living in the tundra were related to a series of variables: colour (white), thickness ("white colour, thick fur and feathers, thick fat stratum)", and height ("small birch trees"). Then a dichotomous enumeration of land and aquatic animals followed.

Text no. 4:

\section{The Arctic Tundra}

"Tundra is an association of grass, moss, lichens, and shrubs. According to latitude and humidity, shrubs and bushes (willows, small birch trees, blueberry) disappear and gramineous plants, moss, and lichens appear. A characteristic feature is the presence of turf moors.

Fauna

The tundra is inhabited mainly by mammals and birds that are adapted to the polar environment (white colour, thick fur and feathers, thick fat stratum). During winter many species migrate to the temperate zone and others hibernate. They find food very hard. For instance, a reindeer needs food from $8 \mathrm{~km}^{2}$ in order to survive. Many animals are adapted both to life on land and in the aquatic environment. Musk ox, reindeer, caribu, polar bear, polar fox, polar rabbit, geese, ducks, and gulls. Many species inhabit the aquatic environment (plankton, fish, whales, seals)." (Cheval, Cheval, Mihai, 1999, Geografie fizică - Manual pentru clasa a IX-a [Physical Geography - Textbook for the $9^{\text {th }}$ Grade], pp. 106-107) 


\title{
VIORICA BLÎNDA
}

The Antarctic tundra was different from the Arctic one as it hosted no land mammals. Why? Because of the thickness of the ice field. The process of creating emblems, the personalisation, and the identification of Antarctic tundra were represented by the presence of penguins.

Text no. 5:

\begin{abstract}
Antarctic tundra
"Moss and lichens grow on the shores of the continent. There are more vegetation species on islands.

Fauna

There are no land mammals. Birds are represented by penguins, albatrosses, and seagulls. Aquatic species are quite many. (Cheval, Cheval, Mihai, 1999, Geografie fizică - Manual pentru clasa a IX-a [Physical Geography - Textbook for the $9^{\text {th }}$ Grade], p. 107)
\end{abstract}

The elements for identifying cold deserts defined through the expression "not covered with glaciers" were described through aspectualisation "rocky surfaces", "interrupted by very small soil patches", at the same time explaining their genesis "through desegregation caused by frost". Another element that individualised them is the low number of species expressed through the restrictive adverb only "only moss and lichens".

Text no. 6:

Cold deserts

They appear in very harsh, continental regions of the polar space where there are no glaciers. Rocky surfaces resulted through desegregation caused by frost are interrupted by very small soil patches. Here only moss and lichens grow." (Cheval, Cheval, Mihai, 1999, Geografie fizică - Manual pentru clasa a IX-a [Physical Geography - Textbook for the $9^{\text {th }}$ Grade], p. 107)

\section{Intersection description}

In the following text authors described several types of lakes according to criteria such as genesis, localisation, size, and economic importance. Authors realised the description by enumerating the names of lakes: Razim, Goloviţa, Zmeica, Sinoie, Siutghiol, Techirghiol, Mostiştea, Oltina, Snagov, Căldăruşani, Herăstrău, Dracşani, Geaca, Izvorul Muntelui, Vidra, and the Vidraru.

Text no. 7:

"Lakes. They occupy only $1.1 \%$ of the territory of our country but they are important not only from a touristic (balneal) point of view, but also because of their fish. The largest lakes are on the seaside, either lagoons, such as Razim (415 $\left.\mathrm{km}^{2}\right)$, Goloviţa, Zmeica, Sinoie, and to the south, Siutghiol, with fresh water, or sea firths, such as Techirghiol, with salty water and curative 


\section{TYPES OF SCIENTIFIC DESCRIPTIONS IN ROMANIAN GEOGRAPHY TEXTBOOKS}

mud, or Mangalia. There are also river firths such as Lake Mostiştea and Lake Oltina to the Danube, or Snagov and Căldăruşani, in the north of Bucharest, that people arranged for leisure and for sailing. In the category of anthropic lakes, traditional are the ponds (e.g. Lake Herăstrău in the northern part of Bucharest), which are more numerous in the Moldavian Field (the largest one is Lake Dracşani in Botoşani County) and in the Transylvanian Field (Lake Geaca). People built many lakes in order to produce with energetic importance, but also for water supply such as Lake Dracşani, for managing flows, etc. The largest ones are Lake Izvorul Muntelui on the River Bistriţa, Lake Vidra on the River Lotru, Lake Vidraru on the River Argeş, as well as other lakes on the River Olt, on the River Sebeş, on the River Siret, etc." (Tufescu, Giurcăneanu, Anastasiu, 2000, Geografia României - Manual pentru clasa a XII-a [The Geography of Romania Textbook for the $12^{\text {th }}$ Grade], pp. 42-44)

Thus, the authors enumerated and described the different types of lakes according to their genesis and used disjunctive argumentative operators: either or, or such as, "sea firths" "or Mangalia," "or Snagov and Căldăruşani".

\section{Attribution and rephrasing through a referential anchor}

The author gave the following theme-title to the following text: "The landforms of our country" which anchors from a referential perspective to the geographical space. The author mentioned again the theme-title through the anaphoric this and rephrased it in the last sequence: "The element that confers a great diversity and uniqueness to the general, regional, and local features of the geographical space is represented by landforms".

Text no. 8:

"The landforms of our country are represented by the substratum where all social and economic activities take place. At the same time, on the surface of these landforms interact natural factors (climate, hydrography, vegetation, soil, geological composition, forms and types of landforms) and the social and economic ones (population, settlements, economic activities, anthropic arrangements), creating a new territory from the perspective of quality that we call the geographical space. This space includes visible elements (geographical landscapes), phenomena and successions (of the geographical environment seen as a system), as well as certain qualitative features that confers this space the attribute of being an environment for man and for the human society). The element that confers a great diversity and uniqueness to the general, regional, and local features of the geographical space is represented by landforms." (Mândrut, 2008, Geografia României - Manual pentru clasa a VIII-a [The Geography of Romania - Textbook for the $8^{\text {th }}$ Grade], p. 7)

\section{Description through aspectualisation}

Description through aspectualisation was promoted by linguist Jean-Michel Adam (1993, 2004, 2007, 2009). In the text below, the first aspect was the genesis, "a form resulted through the accumulation of eruption products - 


\section{VIORICA BLÎNDA}

lava and solid fragments" and then the layout "disposed in strata inclined towards the exterior of the cone," the form which was "having the form of a horn", "having in general a circular or ellipsoidal section"; and the localisation which the authors described through the following phrases "at the superior part of the cone", "deep in the Earth cover".

Text no. 9:

"The main components of a volcanic apparatus are:

- the cone - a form resulted through the accumulation of eruption products - lava and solid fragments known under the name of pyroclastic rocks disposed in strata inclined towards the exterior of the cone;

- the main vent - the access way of magma to the surface, having in general a circular or ellipsoidal section;

- the crater - having the form of a horn, situated at the superior part of the cone ensuring the elimination of magma and of solid fragments during eruptions;

- the magma chamber - the magma source supplying the volcano, situated deep in the Earth cover..." (Cheval, Cheval, Mihai, 1999, Geografie fizică Manual pentru clasa a IX-a [Physical Geography - Textbook for the $9^{\text {th }}$ Grade], p. 28)

\section{Description through comparison and analogy}

In the text below, authors compared wind generated landforms with "sculptures".

Text no. 10:

"Fine rock particles (dust, sand) hit the cliffs which in time become smaller (...). Most of the time, the cliffs eroded by wind start looking as sculptures. This is the result of the wind destructive action." (Strat, Furtună, 1997, Manual de geografie fizică generală, clasa a V-a [Textbook for General Physical Geography. The $5^{\text {th }}$ Grade], p. 51)

In order to support this assertion we chose another text:

Text no. 11:

"In the high altitude mountains, on the peaks situated above the limit of forests and which are usually made of sedimentary rocks that are less resistant to desegregation, wind contributes a lot to creating characteristic forms named after the similarities that they inspired mushrooms, old ladies, sphinxes, columns, etc." (Cheval, Cheval, Mihai, 1999, Geografie fizică Manual pentru clasa a IX-a [Physical Geography - Textbook for the $9^{\text {th }}$ Grade], p. 45) 
The analogy relationship was revealed in the following text through the words "like fingers, elbows", words that derived from the semantic area of the human body: "that penetrate like fingers into the north of the Braşov Depression, between the elbows of the River Olt".

Text no. 12:

"In the south, the central group ends with the low altitude mountains the Perşani, the Baraolt, and the Bodoc, that penetrate like fingers into the north of the Braşov Depression, between the elbows of the River Olt." (Tufescu, Giurcăneanu, Anastasiu, 2000, Geografia României - Manual pentru clasa a XII-a [The Geography of Romania - Textbook for the $12^{\text {th }}$ Grade], p. 14)

The text below offered us another example of description through analogy with human body parts, in order to describe asymmetric types of landforms "called flanks":

Text no. 13:

"This inclination and the hardness of some rocks created the conditions favourable to creating asymmetric landforms called flanks and to their basis appeared asymmetric valleys such as the ones of the Bahlui and of the Bârlad." (Posea, 2000, Geografia României. Manual pentru clasa a VIII-a [The Geography of Romania. Textbook for the $8^{\text {th }}$ Grade], p. 24)

\section{Descriptive inclusion through developing sub-themes}

In the following text the title-theme was "vegetation", including four subthemes: tundra, coniferous forests, evergreen trees and deciduous trees, and deciduous trees forests. The authors described the four vegetation zones according to their localization, through enumerating tree species and the conditions in which these developed.

Text no. 14:

"Natural vegetation is the one that has existed until recently and has been little changed by man. Man has transformed many of the natural vegetation areas into fields for agriculture. The tundra, situated in the north (in Island, in the north of Scandinavia, and of the Eastern European Field), develops in cold climate. Vegetation includes mainly moss, lichens and grass vegetation adapted to cold, and, at the southern limit (where shrubs appear), it includes small birch trees, small willow trees and other species. Coniferous forests (the taiga) occupy the north of Europe and start in Scandinavia and end near the Ural Mountains (they continue in the north of Asia and to the Pacific Ocean). The taiga includes mainly spruce, fir, and pine trees, and species with evergreen leaves. The forests with coniferous and deciduous trees occupy a continuous strip in the south of the coniferous forests. Deciduous trees forests occupy large surfaces in the centre and in the 


\section{VIORICA BLÎNDA}

western parts of the continent; they consist of deciduous trees: oak, beech, elm, lime, maple, and ash." (Mândruţ, Neguţ, 1996, Geografia Europei Manual pentru clasa a VI-a [The Geography of Europe - Textbook for the $6^{\text {th }}$ Grade], p. 20)

\section{DESCRI BING GEOGRAPHICAL LANDSCAPES FROM A SEMIOTIC PERSPECTIVE}

The clue for communicating geographical information in the following text is given by "lake areas" followed by their localization: "along rivers, in deltas and estuaries." The landscape is the result of villages lying along water courses, "gallery type villages", and people built their houses "on pilots" in order to protect them from floods.

Text no. 15:

"In lake areas, especially along rivers, in deltas and estuaries, lineal, gallery type villages are the characteristic feature, with houses built on platforms based on pilots." (Negut, Apostol, 1999, Geografie - Manual pentru clasa a VII-a [Geography - Textbook for the $7^{\text {th }}$ Grade], p. 23)

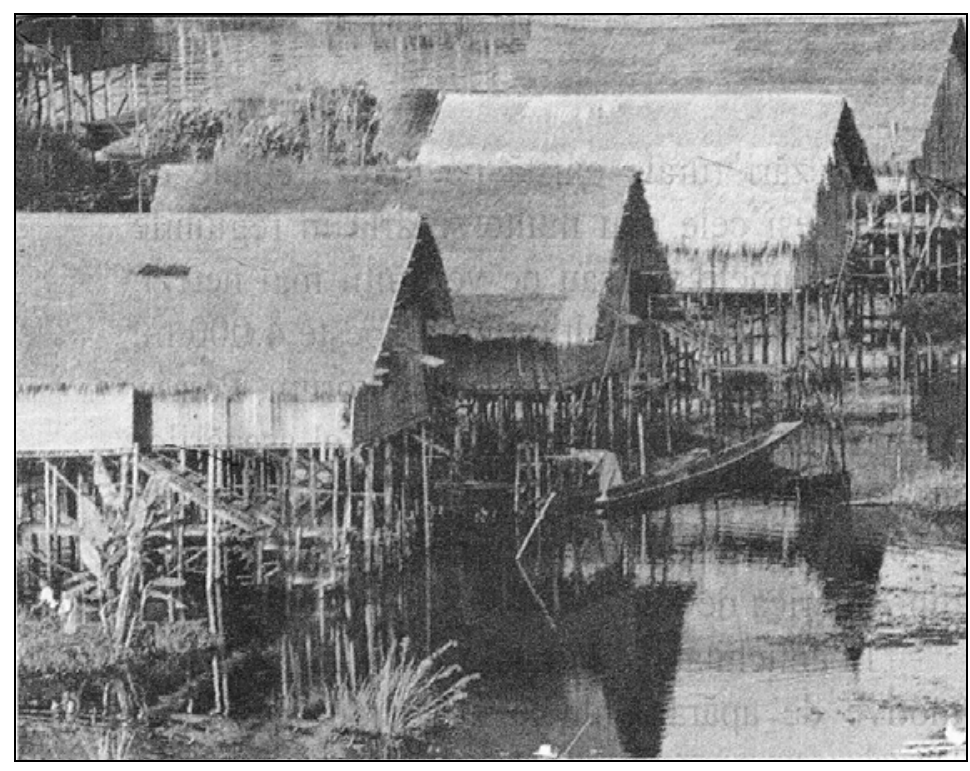

Fig. 1. Village on pilots (Myanmar)

Source: Negut, Apostol, 1999, Geografie - Manual pentru clasa a VII-a [Geography - Textbook for the $7^{\text {th }}$ Grade], p. 24).

The signs in the iconotext above (Figure 1) that describe the lake area landscape were the houses that "were built on platforms based on pilots," 
covered with vegetal construction, a material characteristic of the lake area, a boat, water, and water vegetation.

Making use of our encyclopedic knowledge, we understand that the scientific geographical text together with the iconotext describe a lake landscape characteristic in areas with monsoon rain. By means of semiotic analysis, we may discover and describe the features of geographical objects.

\section{The geographical landscape as myth for identity and patrimonial affirmation}

The description of the natural objectives of the Eastern Carpathians was revealed through enumerations massifs and their emblems: "the Gutâi Mountains with Creasta Cocoşului; the Rodnei Mountains; Rarău Massif with 'Pietrele Doamnei' calcareous cliffs; Ceahlău Massif; the Bistriţa Valley and Lake Izvorul Muntelui; the Bicaz Gorges and Lake Roşu; Hăşmaşu Mare Massif with 'Piatra Singuratică' cliff; the volcanic Lake Saint Ana in the Ciomatu Mountains; Ciucaş Massif with the cliffs 'Tigăile' and 'Sfinxul' nearby Bratocea Pass; Piatra Mare Massif and Postăvarul Massif".

Text no. 16:

"The Eastern Carpathians host many natural touristic objectives among which the most remarkable ones are: the Gutâi Mountains with Creasta Cocoşului; the Rodnei Mountains; Rarău Massif with 'Pietrele Doamnei' calcareous cliffs; Ceahlău Massif; the Bistriţa Valley and Lake Izvorul Muntelui; the Bicaz Gorges and Lake Roşu; Hăşmaşu Mare Massif with 'Piatra Singuratică' cliff; the volcanic Lake Saint Ana in the Ciomatu Mountains; Ciucaş Massif with the cliffs 'Tigăile' and 'Sfinxul' nearby Bratocea Pass; Piatra Mare Massif and Postăvarul Massif. Moreover, they host the balneal-climacteric resorts Vatra Dornei, Borsec, Lacul Roşu, Băile Tuşnad, Covasna, Slănic Moldova, etc. and those for leisure in Poiana Braşov, Borşa, and Durău. Among the cultural, ethnographical, and historical objectives, important are the monasteries from Bucovina (Voronet, Moldoviţa, Suceviţa, Putna, and Humor), the ones at the contact with the Moldavian Sub-Carpathians (Neamt,, Agapia, and Văratec), the wooden churches in the Maramureş Depression, the fortresses in Râşnov, Prejmer, etc. in the Braşov Depression, together with the cultural objectives of Braşov city (the Black Church, Şcheii Braşovului, etc.)." (Tufescu, Giurcăneanu, Anastasiu, 2000, Geografia României - Manual pentru clasa a XII-a [The Geography of Romania - Textbook for the $12^{\text {th }}$ Grade], pp. 111-113)

Their economic importance was revealed through enumerating resorts according to their characteristic features: "Moreover, they host the balnealclimacteric resorts Vatra Dornei, Borsec, Lacul Roşu, Băile Tuşnad, Covasna, Slănic Moldova, etc. and those for leisure in Poiana Braşov, Borşa, and Durău." The text ended with the inhabitants' identity and patrimonial affirmation present in these places: "Among the cultural, ethnographical, and historical objectives important are the monasteries from Bucovina (Voronet, Moldoviţa, Suceviţa, Putna, and Humor), the ones at the contact with the Moldavian Sub-Carpathians (Neamţ, Agapia, and Văratec), the 


\section{VIORICA BLÎNDA}

wooden churches in the Maramureş Depression, the fortresses in Râşnov, Prejmer, etc. in the Braşov Depression, together with the cultural objectives in Braşov city (the Black Church, Şcheii Braşovului, etc.)."

\section{CONCLUSIONS}

Description as a discursive unit stopped being denigrated as it was during the period of classicism. It started to occupy a well-defined place within discourse, especially within the scientific geographical one, where description was the basic discursive unit. Through description, authors underlined the features of beings and of objects and their use in varied contexts until reaching a discursive expansion (Adam, 2007, p. 109).

In the beginning, the discursive sequence started with a simple discursive phrase and through thematic progression, authors organised phrases in descriptive macro-sequences. Description continued with other sequences until obtaining a complete discursive sequence.

Scientific description in comparison with literary description always had a dominant textual function that united a series of features such as: clarity, objectivity, and precision of geographical information (in our case). That enouncement was prolonged in many ways, but, in the end, description as a means of enouncement led to making the text complete.

\section{References}

Adam, J.-M. (1993). La Description, collection Que sais-je?. Paris: Éditions Presses Universitaires de France.

Adam, J.-M. (2004). Linguistique textuelle - des genres de discours aux textes. Une introduction méthodique à l'analyse du discours. Paris: Éditions Nathan.

Adam, J.-M. (2005). La linguistique textuelle - Introduction à l'analyse textuelle des discours. Paris: Armand Colin.

Adam, J.-M. (2009). Textele. Tipuri şi prototipuri. Povestire, descriere, argumentaţie, explicaţie şi dialog. Răspunsuri originale pentru analizele de texte: recunoaşterea secvenţelor. Translated by C. Stanciu. Iaşi: Editura Institutul European.

Charaudeau, P., Maingueneau, D. (2002). Dictionnaire d'analyse du discours. Paris: Éditions du Seuil.

Cheval, D., Cheval, S., Mihai, S. (1999). Geografie fizică - Manual pentru clasa a IX-a. Bucureşti: Editura Teora Educaţional.

Mândrut,, O. (2008). Geografia României - Manual pentru clasa a VIII-a. Bucureşti: Editura Corint. 
TYPES OF SCIENTIFIC DESCRIPTIONS IN ROMANIAN GEOGRAPHY TEXTBOOKS

Mândrut,, O., \& Negut, S. (1996). Geografia Europei - Manual pentru clasa a VI-a, Bucureşti: Editura Corint.

Negut, S., \& Apostol, G. (1999). Geografie - Manual pentru clasa a VII-a. Bucureşti: Editura Humanitas Educaţional.

Posea, Gr. (2000). Geografia României - Manual pentru clasa a VIII-a. Bucureşti: Editura All Educaţional.

Strat, D., Furtună, C. (1997). Manual de geografie fizică generală, clasa a V-a. Bucureşti: Editura Teora.

Tufescu, V., Giurcăneanu, C., \& Anastasiu, V. (2000). Geografia României - Manual pentru clasa a XII-a. Bucureşti: Editura Didactică şi Pedagogică. 